\title{
Mapping Aboriginal nations: the 'nation' concept of late nineteenth century anthropologists in Australia
}

\author{
Kevin Blackburn
}

From the late 18th century to the end of the 19th century, the word 'nation' underwent a change in meaning from a term describing cultural entities comprised of people of common descent, to the modern definition of a nation as a sovereign people. The political scientist Liah Greenfeld called this shift in the definition of the word nation a 'semantic transformation', in which 'the meaning of the original concept is gradually obscured, and the new one emerges as conventional' ${ }^{1}$ The historian Eric Hobsbawm noted that the New English Dictionary 'pointed out in 1908, that the old meaning of the word envisaged mainly the ethnic unit, but recent usage rather stressed "the notion of political unity and independence"' ${ }^{2}$. The political scientist Louis Snyder observed that the 'Latin natio, (birth, race) originally signified a social grouping based on real or imaginary ties of blood'. However by the end of the 19th century the term 'nation' had come to mean an 'active and conscious portion of the population', who shared a 'common political sentiment'. ${ }^{3}$ The work of historians Hobsbawm and Terence Ranger suggests that in the 19th century a nation was not only a cultural group of people of common ethnic origin, but such a group of people who in addition believed that they were a united political entity possessing or desiring sovereignty. ${ }^{4}$

The cultural anthropologist Benedict Anderson has described the idea of the nation as an 'imagined community'. He argued that a nation 'is imagined because the members of even the smallest nations will never know most of their fellow-members, meet them, or even hear of them, yet in the minds of each lives their communion'. The modern nation 'is imagined as sovereign because the concept was born in an age in which the Enlightenment and Revolution were destroying the legitimacy of the divinely-ordained, hierarchical dynastic realm'. The French Revolution, with its ideas of liberty, equality, and fraternity, ushered in the idea of the nation as a sovereign people with a citizenship and possessing defined rights. Anderson noted that the modern idea of a nation 'is imagined as a community, because, regardless of actual inequality

Greenfeld 1992: 4-9.

Hobsbawm 1992: 18.

Snyder, 1954: 29-31.

4. Hobsbawm and Ranger 1983: 6. 
and exploitation that may prevail in each, the nation is always conceived as a deep, horizontal comradeship'. ${ }^{5}$ Was the modern idea of a nation as defined by Anderson as pervasive in 19th century political thinking as various political scientists and historians have assumed? What were the definitions of a nation current in the discipline of anthropology that during the 19th century was involved in the study of communities?

During the late 19th and early 20th centuries, some of the pioneers of anthropology in Australia regularly wrote of how Aboriginal people comprised nations. They drew the boundaries of these Aboriginal nations on maps, which were then published in international anthropological journals. Several early Australian anthropologists, principally AW Howitt and RH Mathews, but also ALP Cameron, John Mathew and William Ridley, had an enthusiasm for delineating and mapping Aboriginal nations. Their impressive array of data was drawn from interviewing Aboriginal people in postfrontier Australia, just after they had been defeated and subdued. From these sources, as well as white informants living in isolated rural areas, they were able to delineate nations and in several cases draw maps of parts of Australia divided into Aboriginal nations, which were further divided into smaller groups that they called tribes. Were these maps of Aboriginal nations representations of cultural groupings rather than maps of nations possessing sovereignty? Perhaps the 'nation' concept used by these men and their contemporaries can be seen in the general context of the existence in the 19th century of a definition of the word nation that pre-dated the modern meaning of what constitutes a nation - a sovereign people. Using Benedict Anderson's words, what type of 'imagined communities' were these Aboriginal nations?

\section{Anthropology and mapping the 'nation' concept}

AP Elkin and Norman Tindale, two Australian anthropologists from the mid-20th century, have described how common this concept of Aboriginal nations in Australia had been among their predecessors, even though they both saw it as erroneous. Tindale, preferring to see the tribe as the basic unit of Aboriginal territorial organisation, noted that these 'less scientific' and 'amateur' early anthropologists incorrectly assigned 'nationlike status to blocks of tribes'. ${ }^{6}$ Elkin also preferred to see the tribe as the unit for the 'modern scientific' anthropologist to study, but he was forced to note how common what he and Tindale called the 'nation' concept had been among the early anthropologists working in Australia. Elkin wrote that 'groups of tribes have been called nations by some writers, but in view of the linguistic differences which usually exist between members of a group and of the lack of any common central organization or sentiment, it would seem inadvisable to use the term "nation" in this connexion [sic]".

The contrast that Tindale and Elkin drew between the 'nation' concept of the age of 'amateur' Australian anthropology and the notion of tribe as a precise term of 'modern scientific' anthropology does not appear to have been an accurate one. In the 1970s, RMW Dixon, an eminent linguist of Aboriginal languages and one of the critics of Tindale's work on the division of Aboriginal Australia into tribes, argued that the 'nation' concept could be fruitfully used to describe Aboriginal groups. Dixon endorsed the

\footnotetext{
5. Anderson 1991: 6-7

6. Tindale 1974: 156.

7. Elkin 1964: 74.
} 
idea of nation put forward by his Aboriginal informant Jack Stewart of the Yidinjdji in the Atherton Tableland. Stewart had explained to him that 'what the Europeans called a "tribe" was more appropriately described as a "nation"', and that 'Aboriginal Australia had many separate nations, just as did Europe (he mentioned France, Italy, Germany, and so on)'. Dixon also mentioned that 'each Australian nation had its own "language"; this would sometimes have a degree of intelligibility with the language of the next nation, and sometimes not'. He compared the Australian nations to the Scandinavian nation-states, 'where several nations speak dialects of a single language, whilst maintaining that they do speak different languages'. He gave Dyirbal as an Australian example: 'a single language, corresponding to six separate Australian nations' - Djirbal, Ngadjan, Mamu, Djiru, Gulnay, Giramay. ${ }^{8}$ Dixon's idea of an Aboriginal nation was not the notion of a 'block of tribes' speaking the same language and sharing similar customs. Nonetheless, Dixon was prepared to acknowledge that the 'nation' concept had validity.

Dixon's example of Jack Stewart, as early as the 1970s, seeing himself as part of an Aboriginal nation similar to France and Germany, and telling anthropologists whom he meets this conception of his people, raises some interesting questions about how the term nation has been used by Aboriginal people to describe themselves. In the late 20th and early 21st centuries, Aboriginal people are telling the Australian legal system through Native Title and land rights claims that they are nations - a term which they use to describe aggregates of tribes who have common purpose in applying for land rights and Native Title. In 1993, Isabel Coe of the Wiradjuri unsuccessfully sought recognition from the High Court of Australia that 'the Wiradjuri are a sovereign nation of people', and demanded compensation for the dispossession of their lands. The case was a landmark one because it was the first time that an Aboriginal community sought legal confirmation of the status as a first nation. Isabel Coe clearly outlined, in the second and third paragraphs of their statement to the High Court, the claim of the Wiradjuri to be seen as a nation that historically possessed a national language, self-government, laws, and boundaries:

2. Since time immemorial, since 1788, since 1813, since 1901 and since within living memory (hereinafter collectively referred to as 'since time immemorial') the Wiradjuri people, who are known as Wiradjuri Kooris and who are included in that group of people known as Aboriginal people, are a nation of persons who have continuously lived on and occupied that land now known as central New South Wales, in whole or in part, according to Wiradjuri laws, customs, traditions and practices, with their own language.

3. The Wiradjuri nation have rights to all [land bounded by the common borders it shares with its neighbours ... and extends from the upper reaches of Wambool (Macquarie) River in its northern border, the Murray River in its southern border, and the Great Dividing Range and the Murrumbidjeri (Murrimbidgee) River in its eastern border and the flood plains of the Kalar (Lachlan) River in its western border and comprises approximately 80,000 square kilometres] and have continued to have rights to the said land by reason of their traditional connection to the said land, notwithstanding any wrongful or unlawful extinguishment, forced dispossession, or forced abandonment of the said land pleaded herein. ${ }^{9}$

8. Dixon 1976: 213-214. 
Interestingly, late 19th century anthropologists mapping Aboriginal nations concurred that a Wiradjuri nation existed. Perhaps the late 19th century ancestors of the Wiradjuri today were telling anthropologists more or less the same as the Wirdajuri were saying to the Australian legal system in the 1990s, and perhaps this helped influence ethnographic practice amongst a group of anthropologists who mapped Aboriginal nations instead of tribes? ${ }^{10}$

From the late 1990s into the 21st century, the Yorta Yorta people - who are sometimes known as the Bangerang - were also engaged in a fight similar to the Wiradjuri for Native Title over 2000 square kilometres of their traditional land along the Murray River in northern Victoria and southern New South Wales. In 1998 the Yorta Yorta/ Bangerang people, like the Wiradjuri, claimed before the Australian Federal Court that they were a nation of people who have continuously lived on and occupied their land, according to their own laws, customs, traditions and practices, with their own language. This Native Title case raised issues over the meaning and significance of Aboriginal people's relationships and claims to land and the modes of their verification and demonstration. The Yorta Yorta/Bangerang, like the Wiradjuri, were also identified as an Aboriginal nation in several maps of late 19th century anthropology. These maps have varied considerably. The work of Rod Hagen, an anthropologist involved in this Native Title claim, suggests that the Yorta Yorta/Bangerang are indeed, in the words of Benedict Anderson, an 'imagined community', and that, although the mapping of their boundaries by various anthropologists from the 19th century to the 20th century has been inconsistent, this community's relationship with their land is still demonstrable and verifiable. Hagen argues that 'a map no matter how questionably drawn has a certain seductiveness about it. Here is something concrete in a situation of ambiguity'. He concludes that 'once lines have been drawn on a map they attain a false concreteness that stands out from the complexities and ambiguities of reality. Boundaries between Indigenous groups are rarely so hard and fast' ${ }^{11}$

Mapping Indigenous people across the whole continent of Australia has been riddled with difficulties, as Hagen has indicated. The three maps that have set out to do this for the whole of Australia in the late 20th century - the Norman Tindale, Stephen Davis, and David Horton maps - have been contentious. ${ }^{12}$ The flaws present in the process of mapping Aboriginal Australia have been explored in Peter Sutton's edited collection of work on the concepts of boundaries, Country. In this work, Elspeth Young observed that the definition of Aboriginal territoriality according to non-Aboriginal concepts of boundaries (precise lines on the ground/maps) is fraught with danger. It is generally not appropriate for Aboriginal groups' ${ }^{13}$

Peter Sutton attributes many of the problems of mapping Aboriginal Australia to confusing two different Aboriginal groups: bands that are the land-using groups, and clans or estate groups that are the land-holding groups. ${ }^{14}$ Bands contain a mixture of

\footnotetext{
9. Coe v Commonwealth, 118 Australian Law Reports, 1993, 193.

10. See McDonald 1998.

11. Hagen 2001: 225.

12. Horton 1994 and 2000; Tindale 1974: 157; Davis and Prescott 1992; Davis 1993.

13. Young 1995: 88.

14. Sutton 1995: 40; and Peterson and Long 1986.
} 
individuals from different clans who together forage parts of the land owned by clans or estate groups. Historically there has been confusion over which Aboriginal group owned the land. Sutton comments that even 'scholars such as Tindale and Birdsell promoted the view that tribes and clans were simultaneously both descent-based categories and physical occupiers of defined land areas which were their territories'. However, it was Nicolas Peterson who was 'perhaps the first to point out this represented a collapsing together of two very different kinds of things: a population and a typological unit (the language group or "formal tribe") ${ }^{\prime}{ }^{15}$

Sutton has noted that 'tribes tend to be among the by-products of the colonial frontier in various parts of the world'. Tribes, as the North American anthropologist Milton Fried has argued, were creations of the European colonisers wanting to order and delineate the colonised population. ${ }^{16}$ Tindale and many others saw the language group as a tribe, which they also believed owned the land. Sutton writes that 'one of the consequences of the impact of the colonial period in Aboriginal Australia has been the rapid rise in the political importance of the language groups.' He added that 'in certain areas, this has become the main collective label under which people maintain a local Aboriginal identity and a communal land-owning group identity.' This was because 'these areas tended to be heavily impacted by the colonial era' to the extent that 'there has usually been a decline, often a complete extinction, of finer-grained forms of classical Aboriginal land-holding such as clans and their estates. The pre-existing category of language group has often become the dominant form of traditional land affiliation'. Sutton observes that 'some of these language groups, or at least sets of people affiliated with them, have become legally incorporated in order to act as fund-receiving bodies'. ${ }^{17}$

Much of the mapping of Aboriginal societies in the 19th and early 20th centuries, according to Young, was an integral part of the colonisation process, 'carried out principally through the alienation of their land and the relocation of Aboriginal groups to government and mission administered reserve communities' ${ }^{18}$ The process of delineating Indigenous nations and identifying their boundaries occurs in considerable detail in the Australian context during the early 19th century. However, maps of boundaries were a rarity. Evangelicals on the Australian frontier, in particular GA Robinson and Edward Parker, used the pre-modern notion of a nation as a cultural rather than a political entity to describe Aboriginal groups in Tasmania and Victoria. During his travels among the Aboriginal people of Tasmania from 1829 into the early 1830s - designed to collect them together so they could be placed on a reserve - Robinson described Aboriginal bands of 50-80 people as nations. When he became Protector of the Port Phillip Protectorate, which was to allocate land for Indigenous people during the colonisation of the area, Robinson continued to use the term, but applied it to a mixture of language groups and clans. Robinson's Assistant Protectors, such as Edward Parker, probably encouraged by Robinson, also adopted the term to describe Aboriginal groups. ${ }^{19}$

5. Sutton 1995: 40

6. Fried 1975: 101.

7. Sutton 1995: 47.

18. Young 1995: 88.

19. Blackburn 2002. 


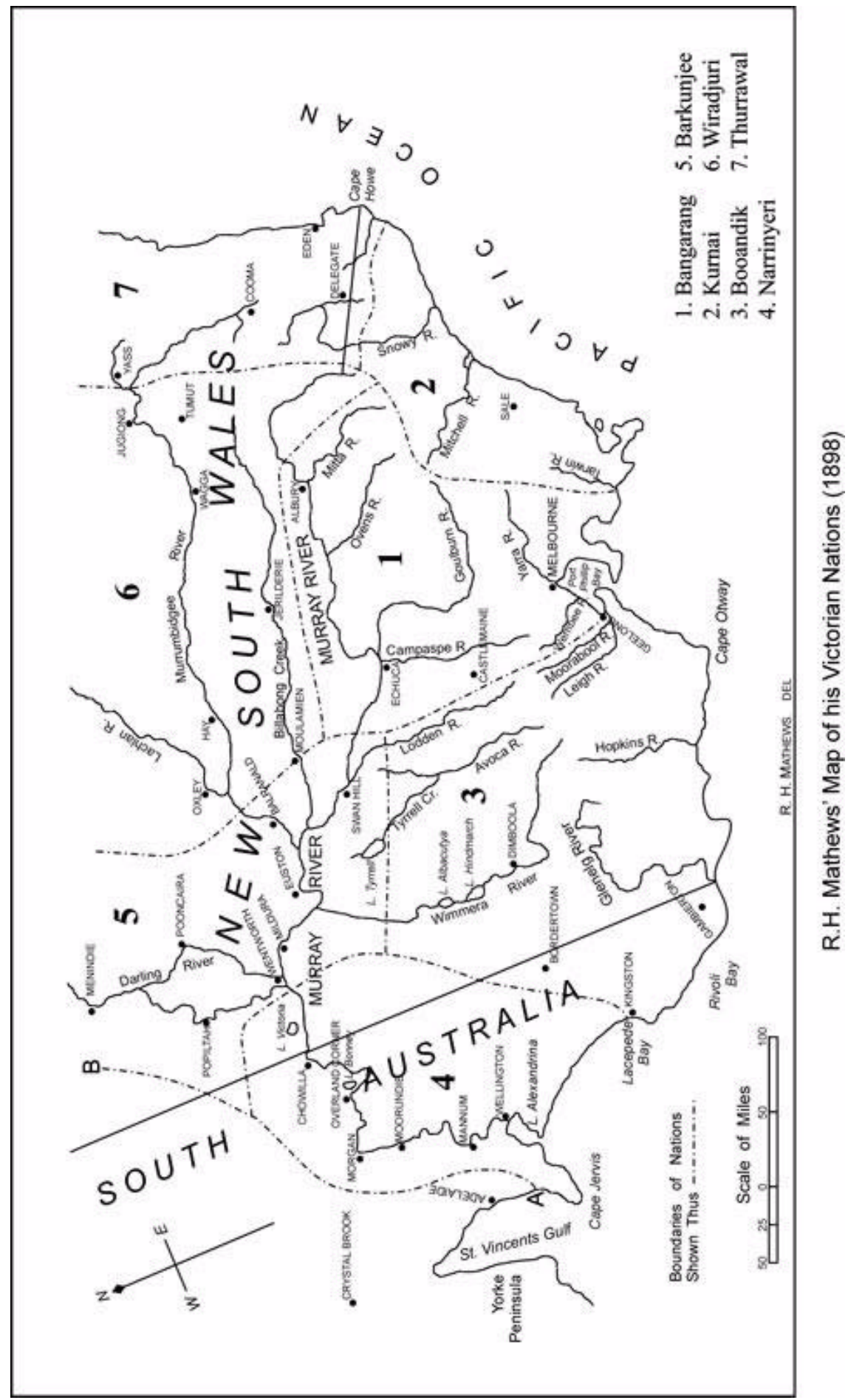


These Evangelicals of the early 19th century used the Biblical notion of a nation as cultural group of common descent, pre-dating 19th century ideas of the nation as a sovereign people. The Evangelicals drew their idea of a nation from that found in the King James version of the Bible: that God had divided humanity up equally, not into races, but into nations, and that people of all nations were capable of receiving God's grace. From Genesis to the Gospels, the King James Version of the Bible refers to many groups of people as nations, eg Genesis 10:32 'the families of the sons of Noah, after their generations, in their nations; and by these nations divided the earth after the flood', and Mathew 28:19: 'Go and teach the Nations, baptising them in the name of the Father, and of the Son, and of the Holy Ghost'.

Although Robinson and his Assistant Protectors regularly used the term nation, they never produced any maps of their Aboriginal nations, despite going to considerable effort to identify their territories. While describing the Aboriginal people of Australia as nations was common among the Evangelicals on the Australian frontier, they never offered a precise definition of what constituted an Aboriginal nation. Only a handful of the Evangelicals of the early 19th century, such as Robinson and his Assistant Protectors, identified particular Aboriginal groups as nations. Despite this, many Evangelicals still described Aboriginal Australia as comprising 'uncivilised' or 'heathen' nations. The existence of the old use of the term nation on the frontier illustrates that the word was indeed undergoing a transformation in meaning, as scholars such as Greenfeld, Snyder, and Hobsbawm have indicated. ${ }^{20}$

\section{AW Howitt and his Aboriginal nations}

Perhaps the first of the pioneer anthropologists in Australia to attempt to provide a rough definition of what constituted an Australian Aboriginal nation in the academic journals of the newly emerging discipline of anthropology was AW Howitt (18301908), a bushman and explorer. Interestingly, Howitt was from an Evangelical background. His father was William Howitt, who had produced the well-known Evangelical text on the relationship between colonisation and Indigenous people, Colonisation and Christianity, in 1838. This text influenced the thinking of many Evangelicals throughout the British Empire. In the text, the elder Howitt morally condemned the process of colonisation practised by nations which he believed could not claim to be Christian because they were engaged in destroying many of what he described as God's 'uncivilised nations'. The younger Howitt appears not to have accepted everything his father believed, because after arriving in Australia and working in the bush he initially adopted a condescending view of Aboriginal people. ${ }^{21}$ However, it is hard not to come to the conclusion, given the unequivocal nature of his father's beliefs, that they did not have at least some impact on AW Howitt. The younger Howitt may have accepted the Biblical notion of a nation when seeing Aboriginal communities because of his father's insistence that they were nations as described in the Bible.

AW Howitt was educated at University College School, London, but spent many of his early years in the Australian outback becoming an experienced and knowledgeable bushman. Howitt found King of the failed Burke and Wills expedition, and returned

20. Blackburn 2002.

21. Mulvaney 1971: 287-8. 


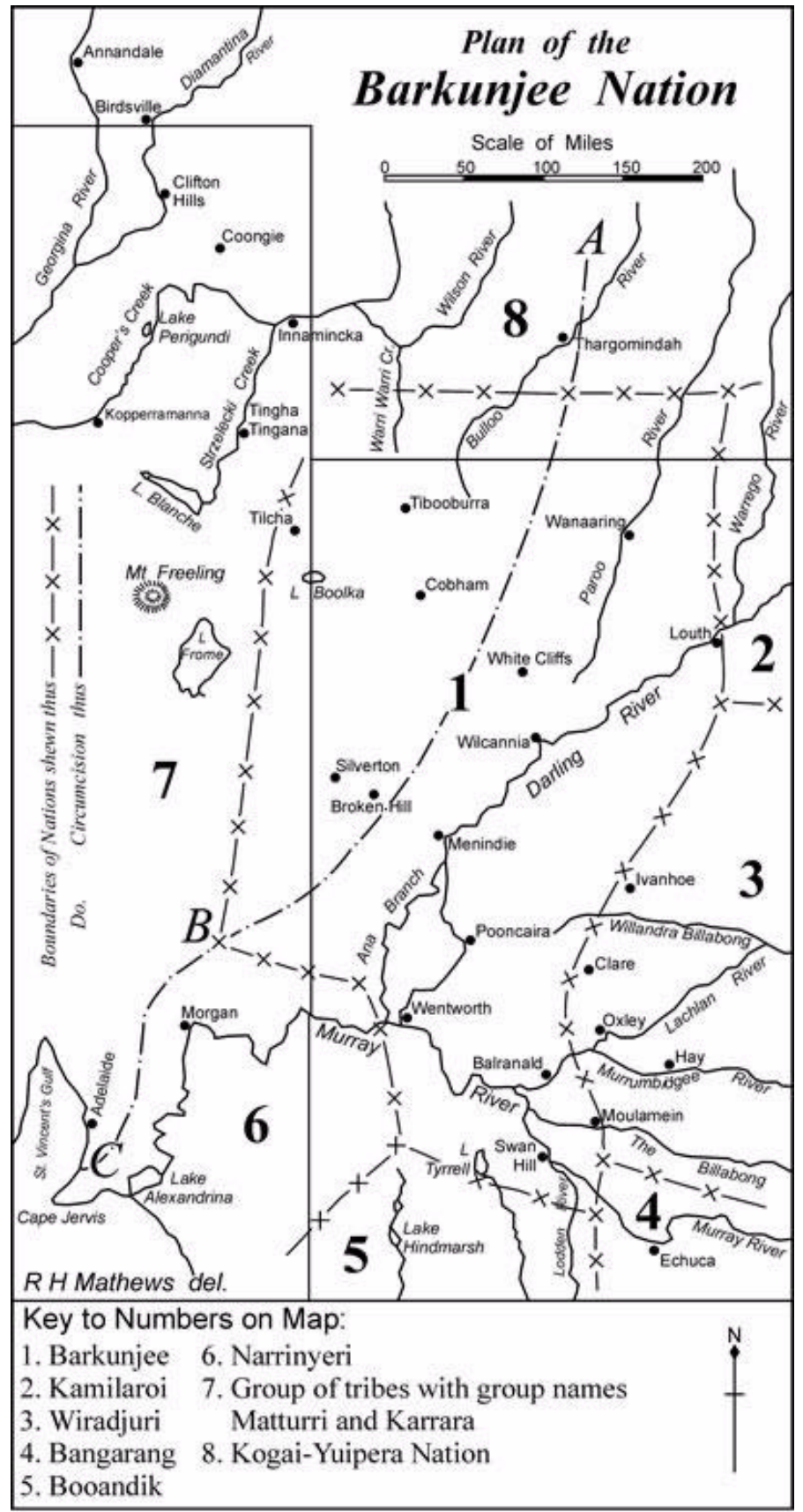

R. H. Mathews' Map of the Barkunjee Nation (1898) 
to bring back the remains of Burke and Wills, as well as to explore the Barcoo region. His many years in Australia as a bushman, naturalist, explorer and then travelling magistrate brought him into close contact with Aboriginal people in isolated rural areas. In his spare time he read the anthropological works of Charles Darwin, John Lubbock, Francis Galton, and EB Tylor. In the 1870s, he was introduced to the anthropological theories of Lewis Morgan by Lorimer Fison, whom Howitt had met when he responded to Fison's public appeal for help in studying Australian Aboriginal kinship systems. ${ }^{22}$

Howitt's belief that Aboriginal Australia was comprised of nations, although probably initially drawn from Evangelical thinking, developed into a more sophisticated concept under the influence of the ideas of Lewis Morgan. The impact of Morgan on Howitt explains how both he, and later RH Mathews, argued that Aboriginal people sharing the same moieties, sections, or class systems comprised nations. These kinship groupings were usually represented by a totem, such as an animal. In his 1877 work, Ancient society, Morgan described how in ancient Athens and Rome, as well as among the Iroquois Indians, tribes having shared moieties or sections (he called them phratries and gentes [sing. gens]) formed into nations. Morgan explained how 'several tribes coalesced into a nation' so that the 'aggregate was simply a more complex duplicate' of the tribes. In his study of the Iroquois nation, Morgan concluded that the 'confederacy rested upon the tribes ostensibly, but primarily upon common gentes'. He argued that 'all the members of the same gens, whether, Mohawks, Oneidas, Onondagas, Cayugas, or Senecas, were brothers and sisters to each other ... Three of the gentes, namely the Wolf, Bear, and Turtle, were common to all five tribes; and these and three others were common to three tribes'. He stated that 'if either of the five tribes had seceded from the confederacy it would have severed the bond of kin, although but slightly'. If war between the tribes had occurred 'it would have turned the gens of the Wolf against their gentile kindred, Bear against Bear, in a word brother against brother' ${ }^{23}$ Morgan's classic 1851 study of the Iroquois made repeated use of the term nation when describing how they were organised. ${ }^{24}$ The impact of Morgan's ideas upon Howitt has long been acknowledged in the history of anthropology as significant. He regularly corresponded with both Fison and Howitt, discussing moieties and class systems. In 1877, Morgan sent Howitt a copy of this book. Howitt wrote back replying that he was in complete agreement with Morgan's volume. ${ }^{25}$ Morgan also wrote the preface to Fison's and Howitt's 1880 book, Kamilaroi and Kurnai, which applied Morgan's classificatory system of kinship to Australia. ${ }^{26}$

The definition of the term nation along the lines outlined by Morgan makes its first appearance in the work of the early Australian anthropologists in a paper by Howitt, read to the Anthropological Institute in Britain by the eminent British anthropologist EB Tylor on 11 December 1883. In this paper Howitt very tentatively noted that there existed 'certain tribes of North-Eastern Victoria, as to which I, at present, know little, except that they belong to that "nation" (if I may use the term) which applied the

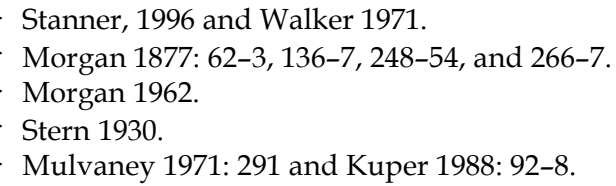




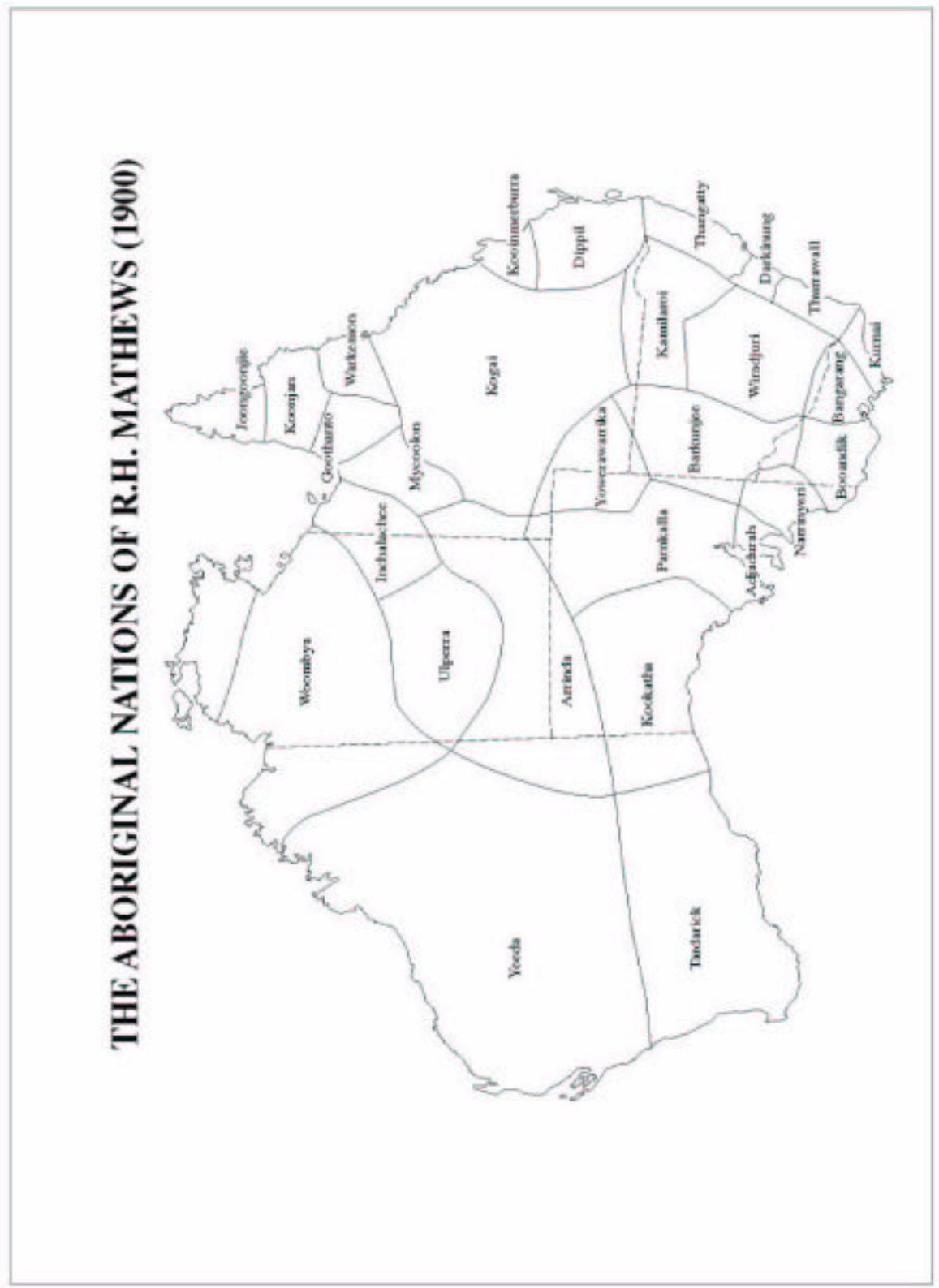


word "Kulin" to its own men...' He defined Aboriginal nations as 'tribal groups' which 'represent a social aggregate, namely a community bound together, despite a diversity of class system, by ceremonies of initiation, which, although they vary slightly in different localities, are yet substantially the same, and are common to all' ${ }^{27}$

Howitt's uncertainty about using the 'nation' concept, conveyed in the 1883 paper, was evident in his own field notebooks. In his notes, dated 1 February 1884, Howitt discussed Aboriginal groups west of the Darling River in terms of nations. He wrote that in his fieldwork he was 'much in want of a name which can be applied to all these allied tribes. They all in some aspects may be regarded as forming a great tribal aggregate for which the word "nation" might be appropriate'. He determined that just as in Victoria, where Aboriginal groups or 'tribes' who use the word 'Kulin' for man 'may be termed the "Kulin nation"', a similar phenomenon could be found along the Darling River in Western New South Wales. Howitt wrote that he had 'found that the word for "Mau = blackfellow" is common to all component tribes', and these 'Darling tribes are known to the aborigines in the South and South East as the "Barkinji"'. Howitt thus delineated a 'Barkinji nation' ${ }^{28}$

Around the same time, Howitt reported in his letters to his colleague, Lorimer Fison, that he had 'unearthed some important information which has enabled me to correct boundaries of Mara ... Kulin ...' nations. ${ }^{29}$ The Mara nation was formed from several tribes on the western boundary of the Kulin. Howitt believed that these tribes 'belonged to a nation calling themselves Mara, "men"', which extended along the sea from Mount Gambier in the west to 'east of Colac, where was the boundary of one tribe of the Kulin nation'. ${ }^{30}$ As for 'the Kulin nation', it 'consisted of a number of Tribes and fell into several subgroups named from the language' ${ }^{31}$ Howitt listed sixteen tribes that made up what he called the Kulin nation. He noted that 'this nation occupied the country from Colac to Mount Baw Baw, and from Wangaratta and Murchison on the north to Port Phillip and Western Port on the South'. ${ }^{32}$

Throughout the 1880s, Howitt attempted to arrive at a clear definition of the 'nation' concept when he described Aboriginal groups. He tried to define the boundaries of Aboriginal nations according to kinship organisation of moieties and class systems. Writing again in the journal of the Anthropological Institute for 1889, Howitt argued that the boundaries of any one class system are usually wider than those of a single tribe, and that the boundaries of a "type" of system have a still wider extent, and include aggregates of tribes which may well be termed nations for they are bound together by a community of classes which indicates a community of descent, and which is usually accompanied by more or less frequent intermarriage' ${ }^{33}$ He again used the

27. Howitt 1884: 433.

28. Notes on the Itchumundi/Karamundi/Barkinji nations, pp. 19-20 in the AW Howitt Papers, Box 1050/7(a).

29. Covering Letter from AW Howitt to Lorimer Fison (undated) in the AW Howitt Papers, Box 1050/7(a).

30. Howitt 1904: 69-70.

31. Covering Letter from AW Howitt to Lorimer Fison (undated) in the AW Howitt Papers, Box $1050 / 7(\mathrm{a})$.

32. Howitt 1904: 70.

33. Howitt 1889: 35. 
term nation to describe Aboriginal societies in an address before the Royal Society of Victoria on 12 December 1889. This paper stated that 'a large group of kindred tribes inhabited an extent of country to the north, south, and west of Melbourne, to which, collectively, the name of the "Kulin nation" may be applied, from the word which in some form of dialect variation was used by them as meaning one of their men'. Howitt claimed, 'my information is derived from Berak, the sole survivor of the tribe, an intelligent and trustworthy old man, who was a boy when Batman first founded Melbourne'. 34 'Berak', or Barak, seemed to be telling Howitt that he perceived himself as a member of a Kulin nation. From the exchanges between Barak and Howitt, it appears that the Kulin were in the words of Benedict Anderson an 'imagined community'. They saw themselves as a Kulin nation. However, sovereignty did not lie with the Kulin nation but with smaller groups within that nation. Thus, the Kulin people were a nation according to the pre-modern definition of the word as a cultural group of common descent, not according to its modern sense as a sovereign people.

In the 1880s Howitt also emphasised that sharing similar languages bound Aboriginal nations together. In a paper in the journal of the Anthropological Institute for 1886, he wrote that 'great aggregates of tribes are frequently marked by the use of a common word meaning 'man' which is restricted in use to their own males'. He added that 'a very large group of tribes having the Kamilaroi organisation might be spoken of as the "Murri Nation" ... [while] similarly, a great group of tribes occupying the country surrounding Lake Eyre, in South Australia, might collectively be spoken of as the "Kurna Nation" [sic]'. Howitt added that 'in Eastern Victoria there would be found a large "Kulin Nation", and a smaller in the south-west of the colony to which the term "Mara" might be applied". He stressed that different Aboriginal words meaning man also helped distinguish the various Aboriginal nations. Howitt declared that there was no word in Aboriginal languages that meant Aboriginal man. He concluded: 'there is no word in the native languages having that meaning. Such words as Murri, Kulin, Kurnai, Mara, have a strictly local meaning. A male aborigine of Victoria is no more a "Murri" than a Scot is a Welshman' ${ }^{35}$

At times Howitt's definition of what constituted a nation was very simple. During 1904, in his major publication, The native tribes of south-east Australia, Howitt gave a very brief definition when he wrote that 'a nation is used to signify a group of tribes'. Howitt's later published work reflected his earlier thinking in his notes, which indicated that language was a key component of his definition. He noted that there are numerous cases in which the word for "man" is common to the languages of a considerable number of more or less nearly related tribes indicating a larger aggregate, for which in default of a better term I use the word "nation"'. Howitt believed that common initiation ceremonies, at which most of the tribes of an Aboriginal nation would gather, helped bind the people together. He described how 'the alliance of tribes forming the nation comes into view on the occasion of one of the great ceremonies being held; all the tribes which form the nation may attend the ceremonies and take part in them, a bond which holds the hordes or clans of a tribe together' ${ }^{36}$

\footnotetext{
34. Howitt 1889a: 109.

35. Howitt 1886: 411-412.

36. Howitt 1904: 41-4
} 
Howitt used tribe and nation interchangeably even in his major published work of 1904. In the same sentence, Howitt used both tribe and nation to describe the Wiradjuri. He wrote that the Wiradjuri were 'a very large tribe or nation of tribes [which] occupy a vast extent of country in Central New South Wales, and distinguished by a common language in dialect forms, the name being derived for Wira, "no"'. ${ }^{37}$ On one page of his 1904 text, he referred to the Kamilaroi as a nation of tribes, and then on the next he used the term tribe. ${ }^{38}$ The Barkinji are also described as a nation on one page, and then called a tribe on the next. ${ }^{39}$ In an 1885 article with Lorimer Fison, Howitt had used the term nation and tribe interchangeably when they wrote that, 'an entire community - nation, tribe, or whatever else it may be called - of Australian blacks is divided socially into two principal exogamous intermarrying sections ${ }^{\prime} .{ }^{40}$ Howitt did not use a strict definition when searching for Aboriginal nations. He usually argued that sharing the same moieties, classes, divisions, or sections bound Aboriginal tribes into nations. However Howitt sometimes saw several nations as having the same classes. In his discussion of the Barkinji and Itchumundi nations along the west of the Darling River, he noted that 'all tribes forming the above-mentioned nations are bound together over an enormous district by the same two class system having the same names for the classes'. ${ }^{41}$

Howitt did not believe that Aboriginal nations were any more than cultural entities; they were not political units. He described how the tribes that comprised the Aboriginal nations, and which were ruled by headmen, were the sovereign political units of Aboriginal Australia. He made no reference to how a nation was governed, only to how tribes were governed. After describing his Aboriginal nations, Howitt was careful to add a footnote in which he wrote that the term nation which I now use must be understood as meaning no more than an aggregate of kindred tribes without implying any kind of confederacy between them' ${ }^{42}$ He used the Kulin nation as an example, noting that the Wurunjerri tribe 'serve as an example of the practice of the tribes which formed the Kulin nation'. He explained that 'the old men governed the tribe and among them were men called Ngurungaeta'. Howitt's Aboriginal informant, William Barak, explained that 'if a man was sensible and, as Barak put it, "spoke straight", and did harm to no one, people would listen to him and obey him'. Barak told Howitt that 'such a man would certainly become a Ngurungaeta, if his father was one before him'. Howitt learnt from Barak that it was a Ngurungaeta, 'who called the people together for the great tribal meetings, sent out messengers, and according to his degree of authority, gave orders which were obeyed'. ${ }^{43}$

The definition of a tribe given by Howitt overlapped with his explanation of the 'nation' concept. Tribe meant 'a number of people who occupy a definite tract of country, who recognise a common relationship have a common speech, or dialects'. He used a similar definition of tribe as he had done for nation when he added that 'the tribespeople recognise some common bond which distinguishes them from other tribes, usu-

37. Howitt 1904: 56.

38. Howitt 1904: 103-104.

39. Howitt 1904: 50-1.

40. Howitt and Fison 1885: 143.

41. Howitt, 1904: 51.

42. Howitt 1886: 412

43. Howitt 1904: 307. 
ally a tribal name, which may be their word for 'man', that is an aboriginal of Australia' ${ }^{44}$ Howitt's tribes appear to have been at some times dialect groups or clans, and bands at other times in his work. Peter Sutton's comment on the existing confusion over whether bands and clans possessed the territory seems to explain Howitt's own illdefined concept of a tribe.

After examining Howitt's printed works and his unpublished journals, the conclusion to be drawn from evaluating his use of the terms nation and tribe is similar to that reached by Diane Barwick, who made an extensive study of the Victorian nations. Barwick suggested that Howitt did not have a clear idea of what he called an Aboriginal nation because he often referred to the same Aboriginal group as a tribe or a nation. ${ }^{45}$ Peter Sutton's and Elspeth Young's opinion that the colonisers arranged the Indigenous people into tribes of people who shared a common language to impose a colonial order upon them seems to apply to the arranging of Aboriginal people into nations. Howitt, too, was engaged in colonisation. As a member of Victoria's Aborigines Board of Protection, Howitt quite happily approved of the process of assigning Aboriginal people to reserves controlled by white administrators. ${ }^{46}$ In this respect, Howitt's ordering Aboriginal people into nations appears similar to anthropologists who wished to describe them as tribes.

\section{RH Mathews' Aboriginal nations}

In the late 19th century, Howitt was not alone in identifying and mapping Aboriginal nations. Howitt and his bitter rival RH Mathews (1841-1918) disagreed on many aspects of anthropology, but both agreed that Aboriginal nations existed and could be mapped. Mathews perhaps derived the 'nation' concept from the work of Morgan and Howitt, but did not acknowledge it. He frequently used the work of Howitt and other early Australian anthropologists without acknowledgment. In the academic journals of early anthropology, Mathews developed the clearest definition an Aboriginal nation in the 19th century and boldly produced maps that clearly showed the boundaries of his Indigenous nations. Mathews was a government surveyor, whose work travelling throughout southeast Australia gave him many opportunities for collecting data from Aboriginal informants. He had grown up as the son of a pastoralist at Mutbilly near Breadalbane, southwest of Goulburn in New South Wales. Many of his playmates were Aboriginal children, and he also knew their parents well. Retiring from surveying in the early 1890s, Mathews devoted himself full-time to anthropological work. From 1894 to 1912, Mathews published over 170 articles in learned journals in Australia, Europe, and America. ${ }^{47}$ Mathews, like Howitt, also came from a strong Evangelical background. According to Isabel McBryde, Mathews was 'a member of the Presbyterian Church and versed in biblical literature', but he was not interested in evangelising, only studying Aboriginal beliefs and ceremonies. ${ }^{48}$ Perhaps Mathews, like Howitt, Robinson, and Parker, drew his inspiration for describing Aboriginal people as nations from the study of the Bible in his own Evangelical background.

\footnotetext{
44. Howitt 1904: 41.

45. Barwick 1998: 10.

46. Walker 1971: 214-215.

47. Elkin 1975: 126.

48. McBryde 1996.
} 
On 16 November 1894, before the Royal Geographical Society of Australasia in Brisbane, Mathews first attempted to outline his concept of an Aboriginal nation. From his study of the Kamilaroi in central northern New South Wales, he noticed that there were 'communities' of tribes. Mathews believed that 'when a number of these tribes are bound together by having the same, or nearly the same, class of laws, participating in similar initiation ceremonies, and among whom intermarriage is more or less frequent, they form communities'. Mathews proposed that 'aggregates of these communities may be called nations'. However, for Mathews, it was not the nation but the tribe that was the political unit of Aboriginal society. He described how 'an Australian tribe is an organised society, governed by strict customary laws, which are administered by headmen or rulers of the various sections of the community, who exercise authority after consultation among themselves'. Mathews' idea of an Aboriginal nation was similar to what Benedict Anderson called an 'imagined community', and the Aboriginal nations identified by Mathews seem akin to Howitt's nations. They appeared to have been 'imagined communities' in that their members believed they belonged, but these 'imagined nations' were not a sovereign people. Sovereignty seems to have been possessed by smaller groups within the nation, which Mathews called 'tribes'. Mathews' idea of a tribe seems to have been similar to Howitt's confusion of dialect groups with clans and bands.

Mathews initially seemed uncertain about suggesting nation as a description. In his early papers he used the term community in preference to nation. He thus wrote about the 'Kamilaroi community' as a group of tribes 'within which the Kamilaroi language was spoken'. Mathews noted that the 'native tribes speaking this language occupied a large tract of rich and well-watered country, extending from the Hunter River in New South Wales to the Maranoa River in Queensland, and constituted a community which was foremost in strength and importance among those of Australia'. Besides the Kamilaroi, there were other groups that Mathews would later call nations but were in this early address designated as 'communities'. He noted that next to the Kamilaroi 'on the south they were joined by the Wiradjuri community'. ${ }^{4}$

In 1898, Mathews returned to the question of delineating Aboriginal nations. He felt confident enough about using the term nation to map what he thought Aboriginal Victoria had been like before the white invasion. He set out what he called 'a short treatise defining the approximate boundaries of the different nations, if they may be termed so, into which the colony was originally divided'. He regretted that 'this work should have been done a half a century ago, while the natives were yet sufficiently numerous to supply the necessary information, but I think it is possible to do something in this direction'. Mathews reiterated his thoughts from 1894: 'I have stated before that when the same several tribes are bound together by affinity of speech, have the same divisional (or class) names, and similar initiation ceremonies, they form communities, and aggregates of these communities may be designated nations ${ }^{\prime 50}$ In his later work Mathews regularly referred back to his 1894 definition of Aboriginal nations, repeating it

49. Mathews 1895: 18-21.

50. Mathews 1898: 325. 
word for word. ${ }^{51}$ His explanation of what an Aboriginal nation constituted appears to have been a thesis, which he tried to test in different areas of Aboriginal Australia.

Mathews sought to arrive at a systematic method of defining an Aboriginal nation. He argued that the first step of any attempt to 'define the boundaries of the nations into which the aborigines were divided' was 'to study the languages and dialects of the population, grouping together those which have an evident affinity'. ${ }^{52}$ For what he called the Kurnai nation of Victoria, he noted that Aboriginal people themselves distinguished speakers who used the word Kurnai (or Kunnai) meaning 'man' as belonging to a Kurnai nation. In New South Wales, the Wiradjuri and Kamilaroi nations were named after the word for 'no' that they used. 'Wira' meant 'no' for all the people who regarded themselves as Wiradjuri; and 'Kamil' was 'no' for all the people who regarded themselves as Kamilaroi. ${ }^{53}$ Mathews was not alone in using these distinctions to separate Aboriginal groups. However many other 19th century observers of Aboriginal people called these units tribes, not nations.

Apart from language, there were shared customs that bound Aboriginal people living in different tribes together into a nation. Mathews believed that the members of the various tribes of a nation were welded into a nation through similar initiation ceremonies, or even a common initiation ceremony at which all the tribes gathered to initiate their young men. In 1894, Mathews depicted the Aboriginal initiation ceremony called a Bora as a 'national rite', where male youths would come from several tribes of the nation to be initiated. Mathews described a Bora of the northern Kamilaroi near Gundabloui, ten miles south of where the Moonie River crosses the Queensland-New South Wales border, in terms of it being an assembly of representatives of an Aboriginal nation: 'The youths who are initiated, are carefully instructed by the old men in their traditions - their moral and religious codes - and the laws of consanguinity and intermarriage', he wrote. 'This national rite partakes partly of a civil, and partly of a religious character, and this is the great educational system by which the exact observance of the laws is inculcated'. Mathews noted that before the Bora was held there were 'messengers sent out to muster the tribes'. For some Aboriginal tribes the journey to the Bora ground was over 150 kilometres. At the ceremony, 'each tribe occupied that side of the main camp which faced the direction of their own tauri, or country'. Even the 23 boys of the three tribes who were to be initiated 'sat in that part of the circle which faced their respective districts'. Over 200 Aboriginal people from the three tribes assembled to witness this 'national rite'. ${ }^{54}$

Mathews argued that these mass gatherings at common initiation ceremonies were integral to the unity of Aboriginal nations because they promoted shared customs and a common culture. He examined in detail their role in the Wiradjuri, the largest Aboriginal nation in New South Wales. Mathews described the Wiradjuri as being like the Iroquois League in North America, 'a vast confederacy' of tribes or 'independent groups', and 'each of which has its recognized hunting grounds'. These tribes 'could be still further divided into smaller groups, consisting, for example, of an old man with his

51. Mathews 1898: 67.

52. Mathews 1902: 71.

53. Mathews 1906: 939.

54. Mathews 1894: 98-129. 
wives, his sons and their wives, and the families of the latter ${ }^{\prime}{ }^{55}$ He described how a Wiradjuri initiation ceremony, or Burbung, strengthened ties between the tribes of the nation: 'the novices of the Hay tribe, for example, would be invested in the garb of manhood by the Narrandara men: the Narrandera boys by the Gundagai men; the Gundagai novices would be dressed by the Hillston men; and the Hillston boys by the Hay men'. Mathews observed that 'novices belonging to one tribe are always dressed in the regalia of a man by the men of one of the other tribes present at the general Burbung gathering' 56

According to Mathews, another characteristic that united Aboriginal tribes into a nation was sharing divisional and sectional names, or having the same moieties. Mathews grouped into nations several neighbouring Aboriginal tribes that were divided into the same two moieties. He noted that a number of tribes could be divided into two social divisions known as moieties, usually signified by a totem, such as an animal or object. Membership of these moieties might be derived from the individual's mother or father, depending on custom, and laws generally prohibited an individual from marrying a person of the same moiety. Tribes comprising a nation might also share a section system, which enlarged the number of social divisions from two moieties to four sections or even eight subsections. When Mathews mapped the Kamilaroi nation he remarked that all of the members of the nation across various tribes were once segregated into two moieties, the Dilbi and Kapathin, which were then increased over time to four sections. He observed that 'as every man, woman and child bore the name of an animal, or some other natural object, one moiety of the community comprising various totems, were grouped together under the collective name of Dilbi; and a corresponding variety of totems adopted the distinguishing name of Kupathin'. ${ }^{57}$ Mathews thus seems to have drawn up the definitions of an Aboriginal nation offered by Morgan and his Australian follower Howitt, but he was more rigorous in his approach.

Although Mathews attempted to arrive at a systematic method of defining an Aboriginal nation, his definition of a nation - like all attempts to define what constitutes a nation - was faced with exceptions and anomalies. Some tribes of the Wiradjuri had sections that were identical with those of the neighbouring Kamilaroi; and sections found in the Kamilaroi extended into tribes that spoke different languages. Mathews had problems testing his thesis because of the destruction wreaked on the Aboriginal nations by the European invaders. He regretted that defining Aboriginal nations was made difficult 'owing to the gradual disappearance of the aborigines before the white population and the consequent extinction of many of the totems'. By the 1890s this had produced circumstances in New South Wales in which 'it is now difficult to find a native who can remember all the totem names, and he will be rather doubtful in regard to those with which he has never had any connection' ${ }^{58}$ Mathews also admitted that he included in some Aboriginal nations several tribes that did not all speak the same language. ${ }^{59}$ Although Mathews tried to map his Aboriginal nations by giving them

\footnotetext{
Mathews 1906: 941.

Mathews 1897a: 129-30.

Mathews 1897b: 157.

Mathews 1897b: 168, 171, and 176.

9. Mathews 1898b: 334.
} 
definite borders, he realised that fixed boundaries did not exist. When he first tentatively suggested that Aboriginal groups could be defined in terms of nations, Mathews had recognised that 'there are no clearly defined boundaries between tribes, or their greater aggregates, the nations - they seem to melt into each other' ${ }^{60} \mathrm{He}$ commented that 'there is generally a narrow strip of "no man's land" between them, which is sometimes occupied by one people and sometimes by the other'. He noted that these boundaries were 'not infrequently defined by hills, watercourses, belts of scrub, stretches of plain, or other remarkable features' ${ }^{61}$

However, despite methodical problems, Mathews held to his idea that Aboriginal nations existed. His 'nation' concept entailed that Indigenous people could be grouped into large national units, although these were not necessarily politically united units. For Mathews, an Aboriginal nation was divided into many sovereign groups. In the case of an Aboriginal nation, he called these sovereign units within it 'tribes'. In the 1890s and 1900s Mathews was consistent in not seeing Aboriginal nations as possessing sovereignty. There were Aboriginal political units that did possess sovereignty, according to Mathews, but these were the tribes that made up a particular Aboriginal nation. Mathews noted that 'a tribe of Australian Aborigines may be described as an aggregation of a number of families or groups, which may, for convenience of reference, be termed subtribes, who speak the same tongue and whose territory is situated within specified geographic limits'. He added that 'these families groups, subtribes, or whatever name we may call them by, find it to their mutual advantage to keep on friendly terms with each other, so that they may be all the better to defend themselves against a common foe, or to make raids upon outsiders'. These tribes had governments: 'There is no kingly rule or arbitrary chieftainship, in one acceptation of these terms, but matters of tribal interest are managed by a sort of informal council composed of the leading men of each local group', Mathews wrote. ${ }^{62}$

Mathews, in an 1898 article written for the journal American Anthropologist, identified and mapped three large Aboriginal nations covering most of the colony of Victoria, with four other nations mainly based in New South Wales and South Australia having boundaries that protruded into the colony. There was a 'Bangarang nation', which occupied much of the land of modern Melbourne and extended north to the New South Wales border. The 'tribes comprising this nation occupied a tract of country in central Victoria which may be approximately defined as being bounded on the north by a line some miles beyond the river Murray, and on the south by the seacoast from Port Philip to the Tarwin river' ${ }^{63}$ There was also a 'Boonadik nation'. He wrote that 'the geographic limits of this aggregate of tribes' were the seacoast from Lacepede Bay in South Australia to Geelong, in Victoria. The third Victorian nation was the Kurnai of Gippsland. Other nations identified by Mathews were mainly based in New South Wales and South Australia, but overlapped into Victoria. These included the Narrinyeri of the Lower Murray River, the Barkunjee at the junction of the Darling and Murray

60. Mathews 1895: 21.

61. Mathews 1906: 941.

62. Mathews 1906: 941 and 943.

63. Mathews 1898a: 326. 
Rivers, the Wiradjuri from the Murray River into central New South Wales, and the Thurrawall along the south east coast of New South Wales.

In the process of identifying the Aboriginal nations of Victoria, Mathews relied heavily upon his methodology of grouping together tribes that possessed common initiation ceremonies and shared divisional names. However his work on Aboriginal territorial divisions of Victoria cannot be taken at face value. Diane Barwick has demonstrated that Mathews' descriptions of Aboriginal territorial organisation in Victoria were often inaccurate and should be treated with caution because Mathews spent very little time in Victoria and mainly relied upon second-hand accounts. ${ }^{64}$

The method that Mathews used to map Aboriginal nations was indeed flawed. In several instances, he just took the name of one tribe and referred to a whole block of tribes by that name. Mathews admitted that he had done this in his maps of a number of Aboriginal nations. In a paper that Mathews read before the Royal Society of New South Wales on 7 December 1898, he described how 'an aggregate of aboriginal tribes, with a social organisation and inaugural rites sufficiently distinct from their neighbours to justify their being ranked as a separate nation, occupy an extensive territory in the western portion of New South Wales'. He added that 'the most widely spread of these tribes is the Barkunjee, and I propose adopting this term for the entire nation' ${ }^{65}$ In Queensland, Mathews identified several Aboriginal nations in areas where little was known of the Aboriginal people, so he made up names to refer to whole blocks of these tribes. The names for these nations were usually taken from the name of one tribe in the area. In 1898, when referring to a group of tribes in the north west Queensland, he wrote, 'I have named this aggregate of tribes the Goothanto nation after the tribe of that name occupying the country around the junction of the Gilbert and Einasleigh Rivers' ${ }^{6}{ }^{6}$

In 1900 Mathews eventually published a map of Australia with 28 Aboriginal nations drawn on it. He affirmed in his article that on his map of the Aboriginal nations of Australia 'aggregates of tribes holding the same divisional names may, for convenience of reference, be called communities or nations' ${ }^{67}$ Many of the Aboriginal nations described were those that he had identified in his earlier research. The size of these nations was defined by the extent of their different moieties and class divisions. For example, the Booandik nation extended as far as its Krokitch and Kamatch moieties. East of it lay the Bangarang nation with its Boonjil and Wah moieties. To the north was the Barjunkee nation with its Muckwarra and Keelparra moieties. For some reason Arnhem Land was completely blank on Mathews' map, perhaps reflecting the lack of knowledge about Arnhem Land at this time. AP Elkin, in his biographical work on Mathews, defended Mathews' inaccurate and very tentative descriptions of Aboriginal territorial organisation and social divisions on the grounds that at Mathews' time very little was known about many Aboriginal groups outside southeast Australia. ${ }^{68}$ However, some of the liberties that Mathews took with the meagre amount of data available

64. Barwick 1984: 100-104.

65. Mathews 1898c: 241.

66. Mathews 1899: 109.

67. Mathews 1900: 575.

68. Elkin 1976: 221-4. 
to him on Aboriginal groups in Western Australia seem to suggest that Mathews was outlining merely a tentative map of Aboriginal nations. His most notable indiscretion was highlighted by Tindale, the criticism concerning Mathews' habit of naming a whole block of tribes after one tribe in the group. Tindale scathingly remarked that in the cases of two Western Australian nations, Mathews 'was without a tribal name therefore had to adopt for one a station or ranch name on the Fitzroy River, namely Yeeda, and for the other in the southwest of Western Australia a family name, Tardarick' ${ }^{69}$

Mathews' motivation to describe Aboriginal people as nations appears to have initially stemmed from his Evangelical background. However, it seems to have been spurred on by his reading of Morgan and Howitt and his desire to establish his own reputation in early anthropology. His definition of an Aboriginal nation displayed a greater theoretical complexity than the nations described in much of the previous writing on Aboriginal societies. Despite this, Mathews, like Howitt, had little respect for Aboriginal sovereignty. He saw Aboriginal people as objects of 'scientific curiosity' which should be taken up by someone such as himself who knew Aboriginal groups well, and not as people who possessed rights.

\section{Aboriginal nations of Cameron, Mathew and Ridley}

There appear to have been other pioneer anthropologists in Australia during the late 19th century who also embraced the 'nation' concept, although not as extensively as Mathews and Howitt had done. ALP Cameron, one of Howitt's informants who lived at Mulurulu, New South Wales, wrote an article in the journal of the Anthropological Institute that gave a definition of the 'nation' concept. ${ }^{70}$ In the 1885 volume of the journal Cameron gave an account of what constituted an Aboriginal nation when he distinguished the word tribe from nation. Cameron argued that the word tribe 'refers to a whole community of people, whose language, laws, institutions, ceremonies, and customs are the same, and who call themselves a certain name'. He added, 'the word "nation" will be applied to a group of kindred tribes who are on friendly terms, and whose language and laws are somewhat but not altogether similar.' He thought 'it probable that there were not more than five or six nations in New South Wales, each nation consisting of from five to twenty tribes ... ${ }^{71}$ Among the Aboriginal nations of New South Wales that Cameron identified were the 'Wiradjeri', the Kamilaroi, and the Barkinji. Cameron was uncertain about the names of the other nations of New South Wales. He described the Wiradjeri as 'a powerful nation, and may have been one of the largest in New South Wales'. He wrote that 'its country extended from Mudgee to Hay, and for a long distance down the course of the Lachlan River'. The Kamilaroi, according to Cameron, 'constituted a nation which was foremost in strength and importance among those of New South Wales'. Cameron was undoubtedly influenced by his friend Howitt's use of the 'nation' concept.

William Ridley (1819-1878), a Presbyterian Minister, also used the 'nation' concept in his early anthropological work of the 1870s. He did not offer a definition of an Aboriginal nation, and used the term more in passing than as a tool for analysis. It is

\footnotetext{
69. Tindale 1974: 136.

70. Howitt 1883: 505.

71. Cameron 1885: 345.
} 
likely that in using the 'nation' concept, Ridley was drawing upon an idea that came from his Evangelical background. In an 1873 research paper, Ridley described a kinship class called the 'Murri' around the Namoi and Barwon Rivers in northern New South Wales. Ridley noted that the 'Murri bear a name almost identical with that of the nation, Murri', and that the 'title "Murri", seems allied to "murra", great or good'. Ridley concluded that the "resemblance of the class name to that of the nation, and to the word signifying great and also good, supports the assertion made by a half-caste of great intelligence who had been brought up with the blacks that the Murri are the first of four classes'. ${ }^{72}$ Ridley's idea of an Aboriginal nation thus seems close to that of Howitt, Mathews, and Cameron, who also saw nations stretching across Aboriginal people with the same kinship divisions and classes.

The influence of Mathews and Howitt on other pioneer anthropologists of the late 19th and early 20th centuries explains why some of their contemporaries applied the 'nation' concept. Tindale identified the Reverend John Mathew (1848-1929) as the last of the pioneer anthropologists to use the 'nation' concept to describe Aboriginal groups in Australia. ${ }^{73}$ Mathew was an elder in the Presbyterian Church, and his Evangelical background perhaps exercised some influence over his desire to use the 'nation' concept. He had grown up in the Wide Bay area around Maryborough in Queensland. As a young manager of pastoralist properties in the area he had learnt the Aboriginal languages of the surrounding Indigenous people before going onto to become a teacher and then to study languages at university. ${ }^{74}$ His use of the 'nation' concept was not as extensive as in Mathews' and Howitt's works, but he seems to have drawn upon their work in his use of the term. Only when Mathew wrote on the organisation of Aborigines in Victoria, which both Howitt and Mathews had written extensively on, did he use the 'nation' concept. In his original work on the Wakka and Kabi people in the Wide Bay area of south east Queensland, where he resided for much of his early life and had a detailed knowledge of the local Aboriginal languages, Mathew never used the 'nation' concept, preferring the term tribes to describe them. ${ }^{75}$ The 'nation' concept is also absent in his early writings on Aboriginal people when he discusses Aboriginal groups across Australia. ${ }^{76}$

In 1910 Mathew, drawing upon the work of Howitt, delineated the Mara and Kulin nations. He stated that 'we observe that the terms which were used as the equivalents of the English word man have been found convenient to divide them into several nations, distinguishable from each other by differences in language, and, to a less extent, in social organization'. Mathew claimed that he was drawing the 'division of the people, first into nations, and then into tribes' ${ }^{77}$ In his manuscript notes on Victorian nations, Mathew quoted Howitt's definition of an Aboriginal nation and indicated how his idea of an Aboriginal nation was slightly different. 'Dr. Howitt may be quoted', Mathew wrote: 'he says ( $p$ 137): "I may note that boundaries of a class system are usu-

\footnotetext{
Ridley 1873: 264.

Tindale 1974: 156.

Prentis 1998.

Mathew 1880: 312-316.

Mathew 1889.

Mathew 1911: 83-5.
} 
ally wider than a tribe, and that the boundaries of any one type of system have a still wider range and include those aggregates of tribes which I have termed nations."' Mathew modified Howitt's definition: 'I would just add that my use of the term nations has a much wider range than Dr. Howitt so as to include within it several class-systems'. Despite his insistence that his definition was different from that of Howitt, Mathew's use of the 'nation' concept demonstrates no appreciable deviation from the work of Howitt. Mathew, like Howitt, claimed that 'a broad principle among the Australian Aborigines that should not be overlooked is presented by what might be called difference of nationality ... The national name is that for man of men' ${ }^{78}$

The use of the term nation by Mathews, Howitt, and their colleagues was not unusual at the time. In 19th century anthropology, the term nation was regularly used as a vague description of a group of people who shared similar customs and were of common descent. However, few in anthropology sought to define nation as Morgan had done in North America, and Mathews and Howitt had attempted in Australia. Anthropologists of the 19th century used the term nation in the general sense that Hodder $\mathrm{M}$ Westropp did when writing in first volume of the journal of the Anthropological Institute in 1872. He saw all the people of the world as comprising nations. Westropp believed that anthropology 'affords one of the most interesting proofs of the intellectual unity of mankind to trace the analogies and unconnected coincidences among the nations'. He wrote that anthropology would reveal 'the same feelings suggested to individuals of the most cultivated nations, and those of the most barbarous'. He quoted Alexander Von Humboldt, the early 19th century naturalist: 'In every nation on earth superstitious ideas assume the same form... ${ }^{79}$ References to North and South American, African, and Australian Indigenous nations occur regularly in the early issues of the journal of the Anthropological Institute. ${ }^{80}$ JS Slotkin's collection of readings in early anthropology also contains many references to Indigenous people being classified as nations. ${ }^{81}$ George W Stocking's work on Victorian anthropology suggests that the term had common currency at least until the end of the 19th century. ${ }^{82}$

By the 20th century the word nation had mostly passed away as a term to describe so-called 'primitive' people. Lucy Mair, an anthropologist of the mid-20th century, noted in her observations of Africa that 'certain large populations which call themselves by one name and speak one language, but do not recognize one common chief or other type of government ... could be called nations', but instead were known as tribes. Mair noted that the word tribe 'has come to be used by people who consider that they are civilized, as a way of describing societies which they do not regard as civilized' ${ }^{83}$ William Sturtevant, a North American anthropologist, has traced the passing of the term nation and its replacement with the word tribe in the 19th century. Sturtevant noted that the terms nation and tribe had been used interchangeably to refer to the

78. Section (A) (d) The Aborigines of Victoria in John Mathew Papers MS 950.

79. Westropp 1872: 221-3.

80. For North and South America see for example Distant 1878: 543-7 and Harper 1877: 324. For Africa see for example Frere 1882: 332 and Mann 1887: 59-64. For Australia see for example MacKenzie 1874: 264.

81. Slotkin 1965: 189, 375, 407-409, 428, 433, and 439.

82. Stocking 1987: 32-3.

83. Mair 1962: 14-15. 
North American Indians in the late eighteenth and early 19th centuries, but by the end of the 19th century tribe had become the only term used. As the word nation started to be increasingly defined as a sovereign people rather than as only a people who had shared customs and were of common descent, Europeans grew increasingly reluctant to describe Indigenous people they were colonising as nations. ${ }^{84}$

Milton Fried, another North American anthropologist, has also noted this shift in terms. Fried attributed it to the rapid spread of European colonisation of the globe in the 19th century and the desire of Europeans to categorise many colonised Indigenous people as not like themselves, living in nations, but as different. ${ }^{85}$ While this transition process was underway in the 19th century, there were anthropologists who used nation interchangeably with the term tribe, although few attempted to be systematic and methodical in the use of the terms. In her history of anthropology Henrika Kuklick suggests that, as anthropology in the early 20th century became more 'scientific' and was increasingly used as a tool for controlling colonised people, Indigenous people became more 'primitive' in the eyes of the Europeans. ${ }^{86}$ Tindale has written that 'with the development of the new interest in field studies on Australian aborigines after World War I, less was heard of the "nations" concept' ${ }^{87}$ In the early 20th century, the fieldwork of anthropologists such as Baldwin Spencer led away from looking for conglomerations of tribes and focused the discipline on small groups for detailed study. ${ }^{88}$

Writing in the mid-20th century, Tindale and Elkin suggested that seeing Indigenous people as nations was merely an oddity resulting from the undeveloped nature of anthropology in Australia in the late 19th and early 20th centuries. However, the opinions of Tindale and Elkin did not reflect the range of views in 20th century anthropology on whether tribes were really small nations; there was a diversity of opinion. AL Kroeber, an eminent American anthropologist of the mid-20th century, took a different view on the 'nation' concept from that of Tindale and Elkin. Kroeber suggested that 'what are generally denominated tribes really are small nationalities, possessing essentially uniform speech and customs and therefore an accompanying sense of likeness and likemindedness'. He noted, however, that 'the genuinely political units were smaller units - corresponding rather to what is customary to loosely call "bands" and "villages". These were defacto self-governing, and it was they that each owned a particular territory, rather than that nationality owned the over-all territory'. Kroeber added that 'ordinarily, the nationality, miscalled tribe, was only an aggregate of miniature sovereign states normally friendly to one another'. There was no distinction, for Kroeber, between Indian nations and Europeans nations. He wrote that "comparing small things to great ones, an Indian so-called "tribe" was therefore likely to be much in the condition of the pre- 1871 Germans who undoubtedly constituted a nationality in view of their common speech, culture, and ideology, but remained divided into 26 sovereign states'. Indian nations, like their European counterparts,

44. Sturtevant 1983: 9 .

85. Fried 1975: 101

86. Kuklick 1991.

87. Tindale 1974: 157.

88. Mulvaney and Calaby 1985. 
could be transformed into nation-states just as 'the events of history in 1871 converted this German nationality into a German nation and state - as corresponding events produced about the same time an Italian national state' ${ }^{89}$

Perhaps Aboriginal nations in Australia can be seen the way Kroeber viewed those of the Indigenous people of North America. Kroeber provides an answer to the question, if the Aboriginal nations of the late 19th century do not form nations in the modern sense of a nation-state, what do they form? The Wiradjuri were identified as a nation by several anthropologists of the late 19th century: Howitt, Cameron, Mathews, and Mathew. From the information they collected from Aboriginal informants it appears that the people were what Benedict Anderson has called an 'imagined community', whose members living in smaller sovereign groups imagined themselves belonging to a larger entity. Kroeber may have been right when he concluded that many Indigenous nations were like Germany before political unification in 1871 . They were not sovereign nations, but cultural entities made up of smaller sovereign groups whose members thought of themselves as a people beyond these small sovereign groups. Barak's description of a Kulin nation that he gave to Howitt, which many Aboriginal people of the area of greater Melbourne felt they belonged to, appears to have been also a similar 'imagined community', although it too did not possess national sovereignty because it was composed of smaller sovereign groups. This interpretation of what constituted an Aboriginal nation confirms Henry Reynolds' work on there being recognition by some Europeans in the 19th century that the smaller groups of Aboriginal society, which they labelled as 'tribes', did possess sovereignty. ${ }^{90}$ However most Europeans in Australia, including the anthropologists using the 'nation' concept, were reluctant to believe that a whole block of what they called 'tribes' could constitute a sovereign nation. ${ }^{91}$ Peter Sutton has observed that the 'finer-grained' territorial groups of parts of Aboriginal Australia, such as clans, have declined due to the onslaught of colonisation, and given way to larger Aboriginal communities who now are organised according to language groups. Today, some of these language and culturally based conglomerations of the smaller 'finer-grained' groups that formed Aboriginal nations, such as the Wiradjuri and the Yorta Yorta/Bangerang, are claiming recognition of the ownership of their territory. The mapping of these cultural nations as identified by anthropologists in the late 19th century has also been problematic and prone to error for the reasons that Hagen, Sutton, and Young have suggested. However, these factors do not negate the existence of Aboriginal nations or reduce the validity of their claims to Native Title and land rights today.

While there were problems with their definitions of an Aboriginal nation and mapping the territory of various Aboriginal nations, anthropologists of the late 19th century who used the 'nation' concept did observe significant aggregates of 'tribes' bound together through initiation ceremonies and marriage. These Aboriginal nations were 'imagined communities' according to Benedict Anderson's definition of a nation. However, they did not form sovereign nations in the modern sense of the term, yet they were nations in the old usage of the word nation, as cultural groups of common

\footnotetext{
89. Kroeber 1955: 303.

90. Reynolds 1996: 24-33.

91. Blackburn 1999.
} 
descent. The prevalence of this use of the word nation on the frontier confirms the point made by Greenfeld, Snyder, and Hobsbawm: that the meaning of the term was under going a gradual transformation to the notion that a nation comprised a sovereign people. The old sense of the word nation still lingered in 19th century political thinking. Nonetheless, the Aboriginal nations, such as the Wiradjuri and the Kulin, were, according to Kroeber, entitled to be considered like Germany before 1871: nations awaiting political unification and national sovereignty.

\section{Acknowledgments}

I would like to thank Marney Dunn, Sam Furphy and David Truginder for research assistance on the Aboriginal nations project.

\section{References}

Anderson B 1991, Imagined communities, revised ed, Verso, New York.

Barwick D 1984, 'Mapping the past: an atlas of Victorian clans 1835-1904: Part 1', Aboriginal History 8 (1): 100-31.

- 1998, Rebellion at Coranderrk, Aboriginal History Monograph No. 5, Canberra.

Blackburn K 1999, 'White agitation for an Aboriginal State in Australia (1925-1929)', Australian Journal of Politics and History 45 (2): 151-80.

— 2002, 'Imagining Aboriginal nations: early 19th century evangelicals on the Australian frontier and the "nation" concept', Australian Journal of Politics and History 48 (2): 174-92.

Cameron ALP 1885, 'Notes on some tribes of New South Wales', Journal of the Anthropological Institute of Great Britain and Ireland 14: 344-70.

Coe v Commonwealth, 118 Australian Law Reports, 1993, 193-208.

Davis SL 1993, Australia's extant and imputed traditional Aboriginal territories, Melbourne University Press, Melbourne.

Davis SL and Prescott, JRV 1992, Aboriginal frontiers and boundaries in Australia, Melbourne University Press, Melbourne.

Distant WL 1878, 'Anthropological gleanings', Journal of the Anthropological Institute of Great Britain and Ireland 7: 543-7.

Dixon RMW 1976, 'Tribes, languages and other boundaries in northeast Queensland', in Nicolas Peterson (ed) Tribes and boundaries in Australia, Australian Institute of Aboriginal Studies, Canberra: 207-238.

Elkin AP 1964, The Australian Aborigines: how to understand them, 7th ed, Angus and Robertson, Sydney.

— 1975, 'RH Mathews: his contribution to Aboriginal studies, part II', Oceania 46 (2): 126-54.

_ 1976, 'RH Mathews: his contribution to Aboriginal studies, part III', Oceania 46 (3): 207-234.

Fried MH 1975, The notion of tribe, Menlo Park, Cummings, California.

Frere HB 1882, 'On the laws affecting the relations between civilized and savage life, as bearing on the dealings of colonists with Aborigines', Journal of the Anthropological Institute of Great Britain and Ireland 11: 313-54. 
Greenfeld L 1992, Nationalism: five roads to modernity, Harvard University Press, Cambridge, Massachusetts.

Hagen R 2001, 'Ethnographic information and anthropological interpretation in a native title claim: the Yorta Yorta experience', Aboriginal History 25: 216-27

Harper W 1877, 'The tribes of British Guiana', Journal of the Anthropological Institute of Great Britain and Ireland 6: 324-8.

Hobsbawm EJ 1992, Nations and nationality since 1870, Cambridge University Press, Cambridge.

Hobsbawm EJ and Ranger, T 1983 (eds), The invention of tradition, Cambridge University Press, Cambridge.

Horton D 1994 (ed), Encyclopaedia of Aboriginal Australia, Australian Institute of Aboriginal and Torres Strait Islander Studies, Canberra.

-_- 2000, Aboriginal Australia, 3rd ed, Australian Institute of Aboriginal and Torres Strait Islander Studies Canberra.

Howitt AW, Papers, La Trobe Library, Melbourne.

-- 1883, 'Notes on the Australian class systems', Journal of the Anthropological Institute of Great Britain and Ireland 12: 496-512.

-_- 1884, 'On some Australian initiation ceremonies', Journal of the Anthropological Institute of Great Britain and Ireland 13: 432-59.

--- 1886, 'On the migrations of the Kurnai ancestors', Journal of the Anthropological Institute of Great Britain and Ireland 15: 409-22.

-- 1889a 'On the organization of Australian tribes', Transactions of the Royal Society of Victoria 1 (2): 96-137.

-- 1889b, 'Further notes on the Australian class systems', Journal of the Anthropological Institute of Great Britain and Ireland 18: 31-70.

-- 1904, The native tribes of south-east Australia, Macmillan, London.

Howitt AW and Fison, L 1885, 'On the deme and the horde', Journal of the Anthropological Institute of Great Britain and Ireland 14: 141-69.

Kroeber AL 1955, 'Nature of the land-holding group', Ethnohistory 2: 303-314.

Kuklick H 1991, The savage within: the social history of British anthropology, 1885-1945, Cambridge University Press, Cambridge.

Kuper A 1988, The invention of primitive society, Routledge, London.

McBryde I 1996, 'Mathews, Robert Hamilton', in Australian dictionary of biography 17881940 CDRom, Melbourne University Press, Melbourne.

McDonald G 1998, 'Master narratives and the dispossession of the Wiradjuri', Aboriginal History 22: 162-79.

MacKenzie A 1874, 'Specimens of the native Australian languages', Journal of the Anthropological Institute of Great Britain and Ireland 3:247-64.

Mair L 1962, Primitive government, Penguin, Harmondsworth.

Mann A 1887, 'Notes on the numeral system of the Yoruba nation', Journal of the Anthropological Institute of Great Britain and Ireland 16: 59-64.

Mathew J, Papers MS 950, Australian Institute of Aboriginal and Torres Strait Islander Studies, Canberra. 
- 1880, 'The Kabi dialect of Queensland', Journal of the Anthropological Institute of Great Britain and Ireland, 9: 312-316.

- 1889, 'The Australian Aborigines', Journal and Proceedings of the Royal Society of New South Wales 23: 335-449.

- 1911, 'The origin, distribution, and social organization of the inhabitants of Victoria before the advent of Europeans', Victorian Historical Magazine 1: 79-89.

Mathews RH 1894, 'The Aboriginal Bora held at Gundabloui in 1894', Journal and Proceedings of the Royal Society of New South Wales 28: 98-129.

- 1895, 'The Kamilaroi class system of the Australian Aborigines', Proceedings and Transactions of the Queensland Branch of the Royal Geographical Society of Australasia 10: $18-34$.

— 1897a, 'The Burbung, or initiation ceremonies of the Murrumbidgee tribes', Journal and Proceedings of the Royal Society of New South Wales 31: 111-53.

- 1897b, 'The totemic divisions of Australian tribes', Journal and Proceedings of the Royal Society of New South Wales 31: 154-76.

- 1898a, 'The Victorian Aborigines: their initiation ceremonies and divisional systems', American Anthropologist 11: 325-43.

- 1898b, 'Australian Divisional Systems', Journal and Proceedings of the Royal Society of New South Wales, 32: 66-87.

- 1898c, 'The group divisions and initiation ceremonies of the Barkunjee tribes', Journal and Proceedings of the Royal Society of New South Wales 32: 241-55.

- 1899, 'Divisions of some Aboriginal tribes, Queensland', Journal and Proceedings of the Royal Society of New South Wales 33: 108-111.

- 1900, 'The origins, organization and ceremonies of the Australian Aborigines', Proceedings of the American Philosophical Society, Philadelphia 39: 556-78.

- 1902, 'The Aboriginal languages of Victoria', Journal and Proceedings of the Royal Society of New South Wales 36: 71-106.

- 1906, 'Australian tribes - their formation and government', Zeitschrift Fur Ethnologie 38: 939-46.

Morgan LH 1877, Ancient society, Charles H. Kerr, Chicago.

- 1962, League of the Iroquois, Corinth Books, New York.

Mulvaney DJ 1971, 'The ascent of Aboriginal man: Howitt as anthropologist', in Come wind, come weather: a biography of Alfred Howitt, by Mary Howitt Walker, Melbourne University Press, Melbourne.

Mulvaney DJ and Calaby JH 1985, 'So much that is new': Baldwin Spencer 1860-1929, Melbourne University Press, Melbourne.

Peterson N and Long J 1986, Australian territorial organization, University of Sydney, Sydney.

Prentis MD 1998, Science race \& faith: a life of John Mathew, Centre for the Study of Australian Christianity, Sydney.

Reynolds H 1996, Aboriginal sovereignty, Allen and Unwin, Sydney.

Ridley W 1873, 'Report on Australian languages and traditions', Journal of the Anthropological Institute of Great Britain and Ireland 2: 257-75.

Slotkin JS 1965(ed), Readings in early anthropology, Aldine, Chicago. 
Snyder L 1954, The meaning of nationalism, Greenwood Press, Westport, Connecticut.

Stanner WEH 1996, 'Howitt Alfred William', in Australian dictionary of biography 17881940 CDRom, Melbourne University Press, Melbourne.

Stern BJ 1930, 'Selections from the letters of Lorimer Fison and AW Howitt to Lewis Henry Morgan', American Anthropologist 32: 257-79 and 419-53.

Stocking GW 1987, Victorian anthropology, Free Press, New York.

Sturtevant WC 1983, 'Tribe and state in the sixteenth and 20th centuries' in The development of political organization in native North America: proceedings of the American Ethnological Society, 1979, Elisabeth Tooker (ed), American Ethnographical Society, Washington.

Sutton P 1995 (ed), Country: Aboriginal boundaries and land ownership in Australia, Monograph No. 3, Aboriginal History Inc, Canberra.

Tindale NB 1974, Aboriginal tribes of Australia: their terrain, environmental controls, distribution, limits, and proper names, University of California Press, Berkeley.

Walker MH 1971, Come wind, come weather: a biography of Alfred Howitt, Melbourne University Press, Melbourne.

Westropp HM 1872, 'On the analogies and coincidence among unconnected nations', Journal of the Anthropological Institute of Great Britain and Ireland 1: 221-226.

Young E 1995, 'Aboriginal frontiers and boundaries', in Country: Aboriginal boundaries and land ownership in Australia, Peter Sutton (ed), Aboriginal History Inc, Canberra: 79-92. 